\title{
HIV infection of non-dividing cells: a divisive problem
} Ariberto Fassati*

Address: Wohl Virion Centre and MRC-UCL Centre for Medical Molecular Virology, Division of Infection and Immunity, University College London, 46 Cleveland Street, London W1T 4JF, UK

Email: Ariberto Fassati* - a.fassati@ucl.ac.uk

* Corresponding author

Published: 26 October 2006

Retrovirology 2006, 3:74 doi:10.1186/1742-4690-3-74

This article is available from: http://www.retrovirology.com/content/3/1/74

(c) 2006 Fassati; licensee BioMed Central Ltd.

This is an Open Access article distributed under the terms of the Creative Commons Attribution License (http://creativecommons.org/licenses/by/2.0), which permits unrestricted use, distribution, and reproduction in any medium, provided the original work is properly cited.
Received: 12 September 2006

Accepted: 26 October 2006

\begin{abstract}
Understanding how lentiviruses can infect terminally differentiated, non-dividing cells has proven a very complex and controversial problem. It is, however, a problem worth investigating, for it is central to HIV-I transmission and AIDS pathogenesis. Here I shall attempt to summarise what is our current understanding for HIV-I infection of non-dividing cells. In some cases I shall also attempt to make sense of controversies in the field and advance one or two modest proposals.
\end{abstract}

\section{Background}

DNA viruses and some RNA viruses must access the nucleus to replicate. This is also the case for lentiviruses and several excellent reviews have been recently published on the subject [1-5]. The interior of the nucleus is separated from the cytoplasm by a double-layer membrane contiguous with the ER called the nuclear envelope (NE) [6]. Embedded in the nuclear envelope are nuclear pores, which are channel-like macromolecules regulating access to the nucleus. In simple functional terms, nuclear pores can be considered like selective filters that allow diffusion of ions and molecules smaller than $9 \mathrm{~nm}$ across the NE and facilitated passage of larger molecules up to $39 \mathrm{~nm}$ in diameter if certain conditions are met [6]. To date, nuclear pores are the only known structures regulating ordered nucleocytoplasmic trafficking. Movement of proteins, mRNAs, tRNAs, rRNAs and nucleoprotein complexes in and out from the nucleus obeys to the selective biophysical nature of nuclear pores [7-11]. Viruses are no exception to this rule, thus understanding the structural and functional nature of nuclear pores is crucial to understand nucleocytoplasmic trafficking of viruses.
Nuclear pores have a maximum diameter of $120 \mathrm{~nm}$, a depth of $180 \mathrm{~nm}$ and an overall mass of approximately $125 \mathrm{MDa}$ in vertebrates [6-12]. Recent 3-D images of Xenopus Laevis oocytes nuclear pores were obtained using energy-filtering transmission electron microscopy and tomographic 3-D reconstruction [13] (Figure 1). The nuclear pore appears to be constituted of two main ring moieties, a larger one facing the cytoplasm and a smaller one facing the nucleus. The two rings are joined together by a central framework, which is perforated by eight peripheral holes with a $10 \mathrm{~nm}$ diameter. The small holes are likely to be the site of ion and small molecules trafficking in and out from the nucleus. The central framework has eight external protuberances that presumably anchor the pore to the nuclear envelope. Flexible filaments approximately $50 \mathrm{~nm}$ long protrude from the cytoplasmic ring. Initially these filaments were thought to be important for the early steps of nuclear transport, by trapping and concentrating cargoes at the entry of the pore [14]. However, it has later been shown that depletion of the cytoplasmic filaments has only a modest effect on the overall efficiency and selectivity of nuclear import processes [15]. Eight filaments of approximately $75 \mathrm{~nm}$ in length depart from the nuclear ring and join the distal ring 
forming the so-called "fishtrap" or nuclear basket [6]. Nuclear pore complexes are composed of approximately 30 different proteins (called nucleoporins), some of which are integral and others are dynamically associated with the main structural scaffold [16]. Several large nucleoporins have phenyalanine-glycine rich domains (FGrich). FG-rich domains are highly flexible and mobile, are mostly unfolded and thus able to interact with many binding partners simultaneously with fast association and dissociation rates [6]. FG-rich nucleoporins are thought to be essential to regulate kinetics and selectivity of nuclear import by constituting a selective gating or permeability barrier to molecules. Although the exact mechanisms are not understood and there are several proposed models $[14,17-19]$, it is clear that nuclear import receptors, such as importins, mediate passage of their cargos through this mesh of FG-rich domains, possibly by conferring to the cargos themselves an overall mildly hydrophobic property and appropriate affinity for certain nucleoporins $[18,19]$. This might be accomplished by the mildly hydrophobic nature typical of all importins examined so far [19]. Importins would then act as "chaperones" for proteins translocating across nuclear pore complexes.

Importins bind to their cargos through recognition of specific domains called nuclear localizing signals. The association or dissociation of importins from cargoes depends on the small GTPase Ran. In its GDP form, it promotes association whereas in its GTP form it promotes dissociation [7-9]. A gradient of RanGTP is maintained across nuclear pores by RanGAP1, RanBP1 and RanBP2 that induce hydrolysis of RanGTP into RanGDP at the cytoplasmic face of nuclear pores. Conversely, RCC1 converts RanGDP to RanGTP in the nucleus. NTF2 transports RanGDP into the nucleus for conversion by RCC1 and thus reconstitution of the nuclear RanGTP pool. So the transport cycle begins in the cytoplasm by binding of the appropriate importin to the cargo in the presence of RanGDP (Figure 2). The cargo can now be chaperoned across the nuclear pore complex. Once the cargo has reached the nuclear side, in the presence of RanGTP, the affinity of the importin for the cargo decreases dramatically and the cargo is released and trafficked to the appropriate nuclear compartment [7-9] (Figure 2). There are exceptions to this rule since some cargoes, like certain hnRNPs, are shuttled across nuclear pores in a Ran-independent way [20-22]. Although energy per se does not seem to be required for translocation across nuclear pores of simple cargoes in vitro, except for the generation of RanGTP, hydrolysable GTP and ATP may be required for nuclear import of large protein or nucleoprotein complexes in vitro and in vivo [23-25].

Interestingly, nuclear pore complexes are dynamic and respond to cellular stimuli. For example $\mathrm{Ca}^{2+}$ induces con- formational changes to nuclear pore complexes and the distal nuclear ring dilates in the presence of $\mathrm{Ca}^{2+}$ or contracts in its absence. Thus the distal ring may function like an iris-like gate and regulate passage of cargoes [12]. The differentiation and proliferative state of the cell is also likely to play a role. Nuclear uptake rate for large particles is significantly higher in dividing cells compared to growth-arrested or serum-starved cells and terminal differentiation has been shown by electron micropscopy to increase both the efficiency of nuclear import and the size of imported particles through nuclear pores [26-28]. The fact that larger particles are imported into the nucleus of dividing cells with greater efficiency suggests that the permeability of nuclear pores may be subject to regulation, perhaps by partly changing the composition of the pores themselves. Moreover, nuclear import may also be modulated by phosphorylation and cell metabolism [29,30]. I propose that different regulation of the rate and overall permeability of nuclear import in dividing versus nondividing cells and in differentiated versus undifferentiated cells is likely to be relevant to nuclear import of retroviruses, as it will be discusses in more detail later.

\section{The challenges facing viruses and the nuclear import system}

Many viruses have to pass through nuclear pores to reach the nucleus, thus three general problems become immediately obvious. First problem, the capsid of many viruses, including adenoviruses, herpesviruses and retroviruses exceed the maximum diameter for passage through nuclear pores. Different viruses have evolved different systems to overcome this limit [31-34]. Some viruses, like adenoviruses, dock their partially disassembled capsids to the cytoplasmic face of nuclear pores, then the capsid completes disassembly by a process called uncoating, which leads to exposure of the viral nucleic acids to the nuclear import machinery. Other viruses, like herpex simplex virus, dock their capsids at the NE and eject the nucleic acids directly into or very close to nuclear pores. Yet other viruses uncoat in the cytoplasm and their genome engages with the nuclear import machinery at an earlier stage. It is likely that the overall structural stability of the intracellular viral capsid, the need to maintain a large genome tightly packed to facilitate cytoplasmic trafficking and the need to carry out enzymatic reactions (as in retroviruses) are all important factors in driving the evolution of different strategies to uncoat and overcome the size limit set by nuclear pores.

Second problem, regardless of how and where the uncoating step takes place, viral nucleic acids must be imported into the nucleus against a steep gradient, since nucleic acids are compacted to a very high density within the nucleus itself (nearly $0.1 \mathrm{~g} / \mathrm{cm}^{3}$ in lymphocytes) [35]. Some bacteriophages might have solved a similar prob- 


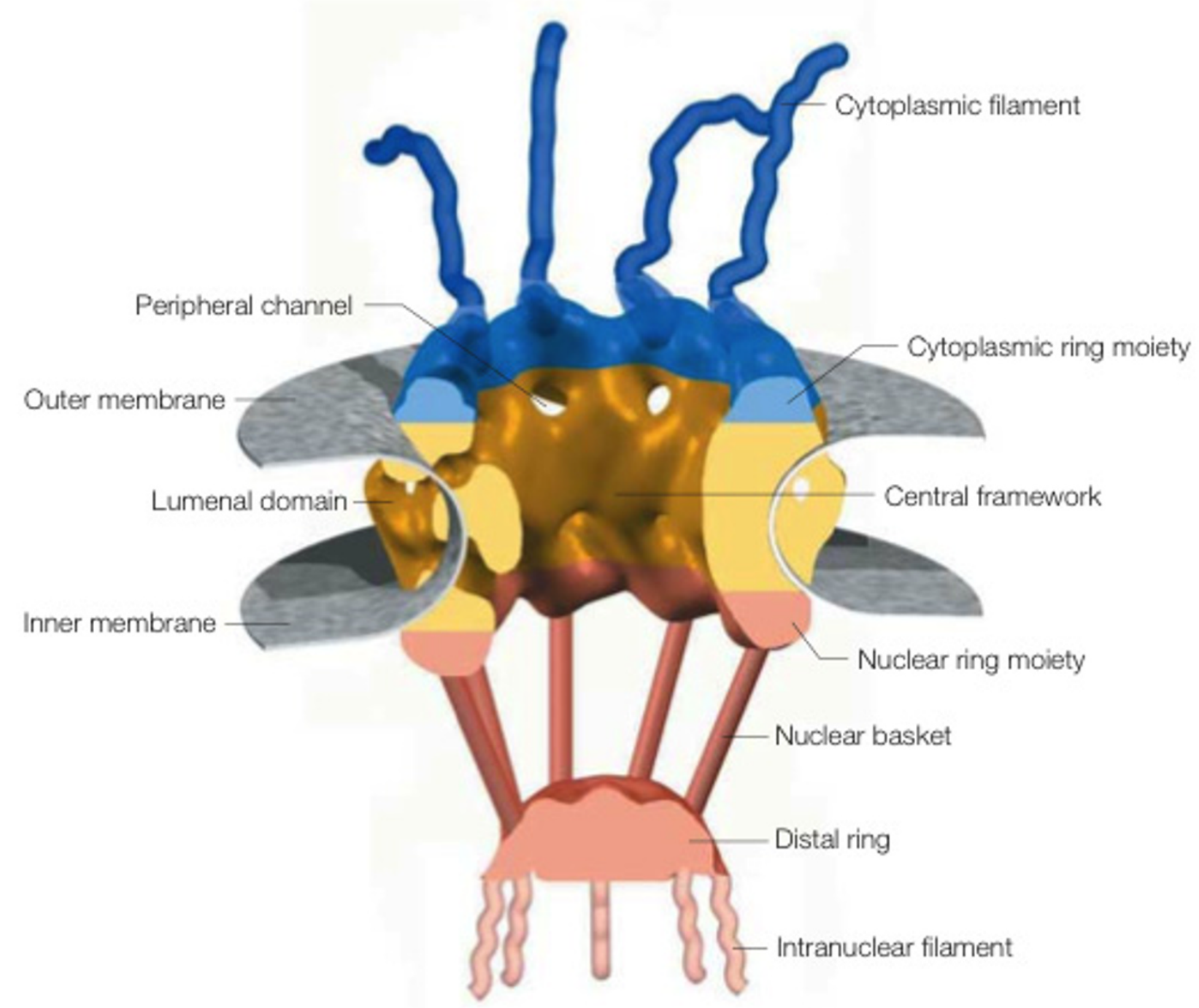

\section{Figure I}

Three-dimensional structure of the nuclear pore complex. The main components of the pore include the central framework (yellow), the cytoplasmic ring moiety and attached filaments (blue), the nuclear ring moiety and the distal ring of the nuclear basket (orange). Nuclear membranes are depicted in grey. Reproduced with permission from Fahrenkrog B and Aebi U, Nature Reviews Molecular Cell Biology 4: 757-766 (2003) Macmillan Magazines Ltd.

lem of introducing their genome into the bacterial host cell by actively packing DNA into their capsid to a very high density with a pressure reaching $6 \mathrm{MPa}$. Such internal pressure is likely to provide sufficient force to inject the phage DNA genome into the bacterial cell at the time of infection [36]. However, there is no evidence so far that mammalian viruses use a similar mechanism to inject their genome into the nucleus.
Third problem, large nucleic acids molecules are charged and hydrophilic. As mentioned earlier, passage through the central channel of the nuclear pore complex depends on hydrophobic interactions with the highly mobile phenylalanine-glycine (FG)-rich domain of nucleoporins [6]. Thus, such large viral nucleoprotein complexes need to be somehow appropriately chaperoned to transit across nuclear pores. 


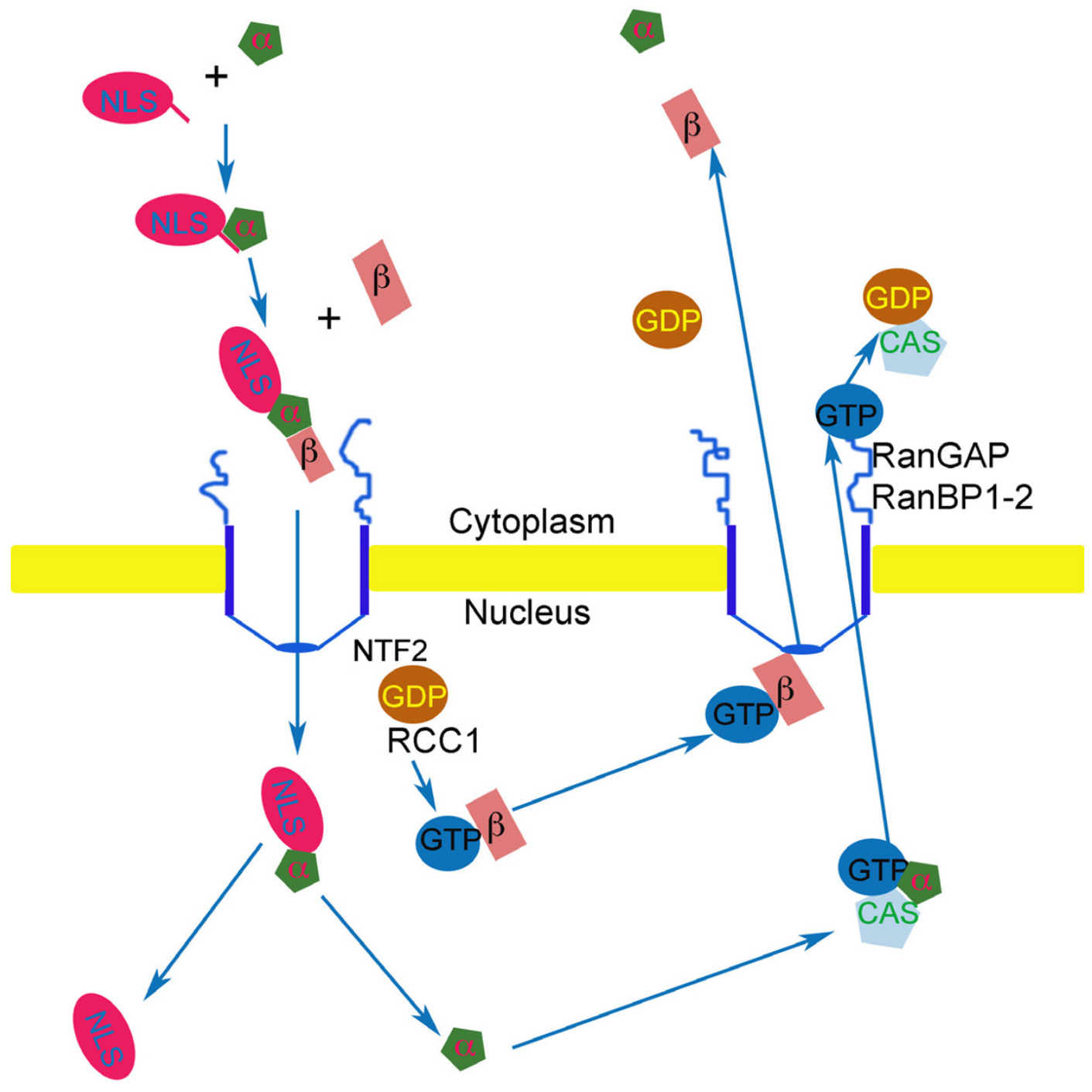

\section{Figure 2}

Schematic representation of the nuclear import cycle. The cargo (red) with a NLS binds imp $\alpha$ and then imp $\beta$ binds to imp $\alpha$ forming a trimeric complex in the presence of RanGDP. The trimeric complex goes across nuclear pores and reaches the inner nuclear region. Here high levels of RanGTP induce a conformational change in imp $\beta$, which dissociates from the cargo and shuttles back to the cytoplasm. Imp $\alpha$ binds to CAS in the nucleus and forms a complex with RanGTP. Such complex is exported from the nucleus and dissociates in the cytoplasm upon conversion of RanGTP into RanGDP. RanGDP is imported into the nucleus by NTF2. In the nucleus, RanGDP is rapidly converted into RanGTP by RCCI. At the cytoplasmic face of the nuclear pore, RanGTP in converted to RanGDP by RanGAP, RanBPI and RanBP2. Thus a gradient of RanGTP across the nuclear envelope is maintained, which gives directionality to the import/export process. 


\section{The interphase nucleus: not every retrovirus's club}

Having broadly defined the general context and problems relative to nuclear import of viruses' genome in mammalian cells, let us now focus on retroviruses.

The ability of lentiviruses to infect terminally differentiated, non-dividing cells has been taken as proof that the genome of such viruses is imported into the nucleus. The inability of simple retroviruses to infect non-dividing cells on the other hand has been taken as proof that the genome of such viruses cannot be imported into the nucleus. The picture is not that clear-cut because different retroviruses infect non-cycling cells with different efficiency.

There is overwhelming evidence that lentiviruses infect non-dividing cells with high efficiency. Caprine arthritisencephalitis virus (CAEV) has increased tropism for differentiated macrophages both in vitro and in vivo [37-39] and can infect dendritic cells [40]. Equine infectious anaemia virus (EIAV) is also found mainly in terminally differentiated macrophages of infected horses [41]. SIV and HIV infect differentiated macrophages, microglial cells and intestinal mucosa resting memory CD4+ T cells [4251]. Clearly, the ability of lentiviruses to infect these types of non-dividing cells is crucial for virus spread and disease pathogenesis. Moreover, HIV-1 was found to be able to infect cells arrested in the cell cycle by treatment with aphidicolin or $\gamma$-irradiation and HIV-1 derived vectors infect hematopoietic stem cells and neurons [52-54]. In fact it appears that passage through mitosis is not a significant alternative pathway for HIV-1 infection even in dividing cells although nuclear envelope breakdown can modestly influence the kinetics of virus association with chromatin [55-57].

On the other hand there is strong evidence that gammaretroviruses can efficiently infect only cycling cells, with one notable exception [58-61]. The block to Moloney murine leukaemia (MoMLV) infection in non-dividing cells is up to 10,000 fold and it is independent of the specific phase of the cell cycle (i.e. G1/S or G2 or G0). The virus can synthesize linear full length DNA but cannot integrate or produce circular 2LTR DNA forms. Alpharetroviruses infect non-cycling cells more efficiently than MLV but less efficiently than HIV [62-67]. Foamy viruses also appear to have some ability to infect non-dividing or slowly dividing cells $[68,69]$, for example they can infect human umbilical cord CD34+ cells and peripheral blood lymphocytes quite efficiently [70-72]. It is possible however that foamy viruses' ability to infect non-dividing cells depends on the long persistence of the pre-integration complex inside infected cells, until division eventually takes place [73].
So, why can lentiviruses infect non-dividing cells and gammaretroviruses cannot? The basis for this difference may reside in the uncoating process $[2,74,75]$. HIV-1 appears to shed its capsid shell quite early during infection, presumably in a manner that is timed with ongoing reverse transcription [76,77]. Evidence to support early HIV uncoating include the very low abundance of p24 CA protein found associated with the reverse transcription complex (RTC) and the PIC, the high density of the RTC/ PIC in linear sucrose gradients, structural and morphological analyses of the RTC by electron microscopy, and the ability of RNA aptamers, siRNA and certain nucleoprotein complexes to interact with the incoming viral RNA genome [76,78-86] (although siRNA targeting of incoming viral RNA is not universally observed [87]). Clearly the viral capsid must remain viable for some time after infection since it is targeted by TRIM5 $\alpha$ and related TRIM5s, which block reverse transcription, perhaps by anticipating the uncoating process itself $[88,89]$. Recent kinetic analyses suggest that the HIV-1 capsid remains viable for approximately 30-60 minutes following entry and after that it can no longer be targeted by TRIM5-CypA [90]. MLV, on the other hand, appears to maintain a capsid shell at least until nuclear entry, as shown by electron microscopy analyses of MLV-infected cells and biochemical studies of the RTC [91-93]. Indeed, substantial amounts of p30 CA are associated with MLV RTCs $[92,93]$. MLV RTCs synthesize full length viral DNA in the endogenous reverse transcription assay in the presence of small amounts of detergent, which presumably help permeabilize the capsid, and the interior of the MLV RTC can be accessed by small molecules but not by antibodies [92].

The viral capsid of both HIV-1 (broad end) and MLV has a diameter of $60 \mathrm{~nm}$ or greater and cannot go across nuclear pore complexes even by an active process. Thus early uncoating may be a necessary, albeit probably not sufficient, step for nuclear import. Two experimental lines of evidence seem to support this possibility. Chimeric viruses in which HIV-1 p24 CA protein has been swapped with MLV p30 CA are unable to infect cells arrested in the cell cycle, hence MLV CA appears to be a dominant-negative factor for nuclear import [74]. HIV-1 p24 CA mutant that fails to dissociate from RTCs also block virus replication at the level of both nuclear import and integration [75].

Although this is an appealing model to explain the phenotypic difference between HIV and MLV, there are some aspects that merit attention. It is likely that MLV is also targeted to the nucleus. For example, MLV mutants in the p1 $2^{\mathrm{gag}}$ protein synthesize normal levels of full length viral DNA but fail to form 2LTR circles, perhaps because they cannot associate properly with nuclear structures [94]. 
Moreover, MLV p30 CA can be SUMOlated and mutants in the p30 CA SUMO target region are blocked in the early phases of replication [95]. This is an intriguing observation because SUMO is involved in nuclear targeting of RanGAP1 to RanBP2, the constituent of the external filaments of the NPC [96]. It is therefore tempting to propose that MLV is actively targeted to components of the nuclear pores, which are known to bind to mitotic spindles during anaphase and early telophase [97]. This would then help tethering MLV PICs to chromatin following cell division. The Fv1 gene might directly or indirectly prevent such interaction between nuclear pore components and MLV PICs and hence prevent PIC nuclear retention, viral DNA circularization and integration.

A recent observation that apparently does not quite fit into the uncoating model for nuclear import suggests that MLV can infect differentiated, post-mitotic macrophages almost as efficiently as HIV-1 based vectors [61]. MLV infection of macrophages is limited to a short time window and it is unlikely to occur in vivo. Nevertheless one can still reconcile this finding with the uncoating model by postulating that NPC permeability in a selected population of macrophages may be greater than usual and allow active passage of macromolecules with a diameter of $60 \mathrm{~nm}$. It will be interesting to test experimentally if this is indeed the case. As mentioned earlier, NPC permeability changes depending on the metabolic state of the cell, its differentiation and its ability to divide. Alternatively, MLV PICs may persist longer in macrophages until some degree of uncoating takes place allowing nuclear import.

\section{Nuclear import of HIV-I, facts and controversies} Uncoating of the viral capsid is likely to be a pre-requisite for nuclear import but specific signals and import factors are also likely to direct intracellular trafficking of the RTC/ PIC. Several such nuclear localisation signals (NLS) have been identified in the HIV-1 PIC but no unequivocal picture has emerged yet. The first NLS within the HIV-1 PIC was reported in the $\mathrm{N}$-terminal region of p17gag MA and mutation of two lysines at position 26 and 27 was shown to block HIV-1 replication in terminally differentiated primary macrophages but not in proliferating cells [98]. These observations were quickly confirmed although it appeared that Vpr also influenced HIV-1 infection of nondividing cells in addition to MA $[80,99]$. Moreover, phosphorylation of MA on a C-terminal tyrosine ( $\left.\mathrm{Y}^{131}\right)$ was reported to induce MA incorporation into PICs (via binding to integrase) and to be essential for HIV-1 infection of non-dividing cells [100,101]. A more complex picture of MA phosphorylation was proposed later since mutation of MA $\mathrm{Y}^{131}$ did not appear to have an effect on virus replication [102,103].
Subsequently, however, three studies could not confirm the presence of an NLS in MA [103-107]. The phenotype of HIV-1 mutants in the N-terminal MA NLS also remained controversial. Whilst such mutants were originally reported to be severely and selectively impaired in primary macrophages, later reports showed that they were moderately ( 2 to 15 fold) defective in both dividing and non-dividing cells using spreading assays and single-cycle assays [104,105]. Remarkably, HIV-1 mutants with large deletions of the MA N-terminal region or even lacking the entire MA (but retaining a short N-terminal myristoylation signal) have been shown to still be able to replicate in both dividing cells and macrophages, albeit at reduced levels [108].

More recently, MA has been reported to have a CRM1dependent nuclear export signal (NES). Mutations in this NES at position 18 and 22 of MA were shown to cause nuclear localisation/retention of viral RNA and severely impair HIV-1 infectivity. Furthermore, the NES has been proposed to override a presumably masked NLS in the context of the p55gag polyprotein [109]. It is somewhat difficult to reconcile these latter findings with earlier work showing that deletions of MA from residues 8 to 87 have a modest effect on HIV-1 replication [108], yet differences in the HIV-1 strains used might at least in part account for the different results. It is also interesting that the NLS and NES in MA would appear to be separated by 4 residues only $[98,109]$, although a novel NLS in MA has been reported [110]. In summary, although there is no agreement on the existence of a NLS in HIV-1 MA $[98,105-$ $107,109,111]$, there appears to be some consensus that mutations in the N-terminal region of MA have a moderate effect on virus infectivity in macrophages as well as other dividing cell types. Since such an effect is also detected in single-cycle assays, it is likely to involve some early, post-entry event.

The viral protein $\mathrm{R}(\mathrm{Vpr})$ has been shown to play a role in HIV-1 nuclear import (for a recent review on this subject please refer to [112]). The general consensus is that $\mathrm{Vpr}$ is a karyophilic protein. Indeed Vpr localises to the nucleus when expressed on its own and also possesses at least two transferable NLSs that induce nuclear accumulation if fused to larger proteins like the maltose binding protein or $\beta$-galactosidase [113-118]. Vpr also localises to the nuclear envelope, possibly by direct engagement with nucleoporins [116-119]. The pathways used by Vpr for nuclear import are not completely clear. $\mathrm{Vpr}$ is a small protein of 96 aminoacids and contains no canonical (SV40 T antigen/importin $\beta$ binding domain [IBB] NLS). The N-terminal region of Vpr contains a NLS, which can bind to importin $\alpha$ and nucleoporins [116,118] yet $\mathrm{Vpr}$ is not imported into the nucleus by the importin $\alpha /$ importin $\beta$ heterodimer [116-118,120]. An additional trasferrable 
NLS has been detected in the C-terminal region (aa 7396), which uses a pathway distinct from the N-terminal NLS. Both C- and N-terminal NLSs were shown to use a Ran-independent pathway and to require minimal energy [117]. It has been proposed that Vpr bypasses the normal requirements for nuclear import like Ran-dependent interaction with nuclear import receptors and instead can bind directly to nucleoporins, similar to importin $\beta$ family members [117,118].

Importantly, $\mathrm{Vpr}$ is incorporated into virions at high levels via its interaction with the $\mathrm{p} 6$ domain of p55gag [121]. The ability of Vpr to be incorporated into virions and enhance infectivity in macrophages might in addition depend on its nucleocytoplasmic shuttling properties and to a NES located in the C-terminal region, although this possibility is contentious and $\mathrm{Vpr}$ nuclear export may be more important in regulating cell-cycle arrest $[122,123]$. Vpr is retained in the RTC/PIC $[76,80,83,124]$. Thus, it has been proposed that Vpr stimulates docking of the RTC to the nuclear pores or alternatively disrupts nuclear envelope and pores to alter nuclear permeability $[125,126]$. Indeed many studies have shown that mutations in Vpr reduce HIV-1 ability to replicate in different cell types, including macrophages and PBMCs $[80,116,118,127]$. The replication defect is greater in cells infected a low MOI but is only a few fold. Consistent with this phenotype, HIV-1 based vectors that do not encode Vpr are still able to infect macrophages and other non-dividing cell types [128]. Moreover, Rhesus monkeys infected with SIVmac strains with a mutation in $\mathrm{Vpx}$, which is the gene for nuclear import corresponding functionally to HIV-1 Vpr [129], showed lower virus burden, delayed decline in CD4+ counts but eventually progressed to AIDS [130]. Similarly, SIVsm strains mutant in Vpx also showed delayed replication kinetics in pigtailed macaques, possibly due to reduced virus amplification at early, post-transmission stages [131]. Taken together, these data suggest that the nuclear import properties of HIV-1 Vpr are probably not essential for virus replication but may increase HIV-1 infectivity and ability to propagate in specific cell types.

Integrase remains stably associated with the RTC and later the PIC and is the necessary protein for integration of viral DNA into host chromosomes. Because of its tight association with the PIC even after nuclear entry, integrase would be a good candidate to mediate HIV-1 nuclear import. HIV-1 integrase (IN) is karyophilic but there is some disagreement on the mechanisms regulating IN trafficking into the nucleus. Most investigators have reported that IN is imported into the nucleus by an active, saturable and energy -dependent mechanism. Putative NLS have been mapped to several regions of the C-terminus of IN $[111,132-134]$ and to the central catalytic domain $[135,136]$, although some of these putative NLSs have been questioned $[133,137,138]$. Moreover, IN can bind to importin $\alpha[25,111,138]$, to importin $\beta$ directly $[25,138]$ as well as to importin 7 and transportin [25]. At least importin $\alpha$, importin $\beta$ and importin 7 have been shown to stimulate nuclear accumulation of IN in a Ran-dependent way [25] and in one recent study blocking antibodies against importin $\alpha$ and/or importin $\beta$ were shown to reduce IN nuclear import [138]. Antibodies against importin 7 did not block IN nuclear import in one study [138], however it is not clear which anti-imp7 antibodies have been used in that study and to our knowledge antibodies with good affinity for native importin 7 are not available. Therefore those negative results should be interpreted with caution. Interestingly, it has been recently reported that HIV-1 Rev binds to and is imported by a number of importins, including importin $\beta$, importin 7 and transportin [139]. The adenoviral pVII protein, which is tightly bound to the viral DNA and is thought to mediate nuclear import of the adenoviral genome, has also been shown to bind to and be imported by the imp $\alpha / \beta$ heterodimer, imp $\beta$ alone, imp7 alone, imp7/ $\beta$ heterodimer and transportin [140]. Thus adenoviral pVII protein and HIV-1 IN appear to behave in a remarkably similar way $[25,140]$. Adenoviral pVII and HIV-1 Rev and IN are all small, basic nucleic acids-binding proteins and may share similar nuclear import pathways. Moreover, relying on multiple importins may give a selective advantage to viruses by maximising nuclear import efficiency in different conditions and cell types. It is plausible that some ribosomal proteins have adopted a similar strategy to ensure their efficient nuclear import [141].

Lentiviral INs specifically bind to lens epithelium-derived growth factor (LEDGF/p75), a hepatoma-derived growth factor that interacts with DNA and this association has been reported to be important for IN nuclear localisation $[142,143]$. IN and LEDGF/p75 have been shown to colocalise in nuclei following transfection of plasmids encoding for the two proteins. Mutant IN unable to interact with LEDGF/p75 was shown to have lost its ability to accumulate into nuclei and siRNA-mediated knock down of LEDGF/p75 induces re-localisation of exogenously expressed IN to the cytoplasm [143-146]. These data point to the possibility that LEDGF/p75 mediates nuclear import of IN. However, pre-incubation of LEDGF/p75 with IN did not stimulate IN nuclear import in the nuclear import assay [145]. Severe knock down of LEDGF/p75 inhibits HIV-1 infectivity at the level of integration but not appreciably at the level of RTC nuclear import and the nuclear rather than the cytoplasmic pool of LEGDF/p75 appears to be the important for HIV-1 replication ([147]; E. Poeschla personal communication). Since IN is readily ubiquitinated in stably expressing cells lacking LEDGF/ p75 [144], such modification might cause loss of IN nuclear import. 
Is it possible to reconcile these findings with the observation that, at least in vitro, IN can be imported into the nucleus by an active mechanism in the absence of LEDGF/ p75? It is perhaps interesting that the integrase-binding domain in LEDGF/p75 is structurally closely related to the HEAT repeat found, amongst other proteins, in importin $\beta$ and other importins [148]. It is therefore tempting to speculate that the very same region in IN mediating LEDGF/p75 binding also mediates interaction with importins via the HEAT motif. If this is the case, then alternative binding of LEDGF/p75 and importins might take place. Importins binding to IN might prevail in the cytoplasm due to their relative abundance in this compartment whilst LEDGF/p75 binding to IN might prevail in the nucleus, following dissociation of importins from IN in the presence of RanGTP. Then LEDGF/p75 might tether IN to chromosomes and stimulate HIV-1 DNA integration. A prediction of this model is that LEDGF/p75 competes with importins for binding to IN in the absence of RanGTP though one would expect LEDGF/p75 to bind to IN with greater affinity than importins.

Alternatively, lentiviral INs per se might not have a transferable NLS as shown by two reports $[149,150]$ and nuclear accumulation could simply be the result of diffusion across nuclear pores, DNA binding and nuclear retention. LEDGF/p75 tethers IN to chromosomes, hence it might appear to induce nuclear import.

Finally, a few words of caution should be spent on the role of IN in HIV-1 nuclear import. There is limited information on the precise conformation of IN within the RTC/ PIC and several domains, which are exposed in the recombinant protein, might not be available once the protein is part of the RTC/PIC and bound to nucleic acids [132,151]. Moreover, it is now clear that IN serves multiple roles in addition to viral DNA integration and that mutating putative IN NLSs may result in unexpected phenotypes unrelated to nuclear import $[132,152-156]$. Thus, it has proven a rather difficult task to translate results obtained in vitro by mutagenesis of IN into a clear phenotype of reduced HIV-1 nuclear import. Remarkably, a recent study has analysed the phenotype of HIV-1 chimeric viruses bearing MLV IN in place of HIV-1 IN and shown that such mutants are attenuated but still able to infect non-dividing cells. Only a small increase was observed in the ratio of cytoplasmic to nuclear viral DNA in cells infected with the mutant virus compared with wild-type HIV-1 [157]. Thus, it is possible that IN does not play an important role in HIV-1 nuclear import, although it should be noted that MLV IN has also been shown to rapidly accumulate into the nuclei of infected cells [91].

The central polypurine tract ( $\mathrm{CPPT}$ ) was also shown to influence HIV-1 nuclear import. The CPPT is a second ori- gin of DNA plus strand synthesis located in pol, it is present in all lentiviruses and results in a short (approximately $100 \mathrm{nt}$ ) stretch of triple stranded DNA upon completion of reverse transcription $[158,159]$. Absence or mutation of the CPPT was shown to abolish HIV-1 replication in a spreading assay and to reduce infectivity by $5-7$ fold in single cycle infection assays using HIV-based vectors. Reduced 2LTRs circular viral DNA formation and hence nuclear import was reported to be the main defect of the mutant viruses $[160,161]$. This observation has been confirmed by many studies using HIV-1 based vectors in several cell lines and primary human cells, including PBMCs, T-lymphocytes, macrophages, CD34+ cells and in rat neurons [162-165]. Indeed it is now standard practice to include the cPPT element in the design of "second and third generation" lentiviral vectors. A few features of the phenotype of cPPT+ vectors are worth noting. First, the cPPT+ vectors have increased infectivity in both dividing and non-dividing cells. Second, cPPT+ vectors appear to have an increased rate rather than an absolute increase of HIV-1 DNA nuclear transport. Third, there seem to be a slight increase in integration efficiency with cPPT+ vectors and fourth, cPPT+ vectors are able to overcome a saturation effect seen with cPPT- vectors, hence they work better at high MOI [162-165]. This would lend support to the hypothesis that the cPPT can "boost" HIV1 vector infection bypassing (partially) the requirement for some limiting cellular factor important for nuclear import.

The picture becomes more complicated when wild type viruses with a normal or mutated CPPT are tested in spreading assays. In this case a modest attenuation of CPPT- viruses is seen only in some cell types and even in single cycle assays the difference between cPPT- and CPPT+ viruses' infectivity has been reported to be approximately two fold $[153,154]$. A similar degree of inhibition has been observed with the yeast Ty1 retrotransposon lacking the CPPT element [166]. The reasons for this discrepancy are not completely clear. One simple explanation would be that virus growth in spreading assays is generally measured by p24gag ELISA or by enzymatic RT assays and both assays have higher variability than GFP detection by FACS in single cycle assays. Thus, if the variability of the detection assay is greater than the experimental difference to be observed, the results cannot be accurately measured. Alternatively, a difference in the rate rather than absolute amount of HIV-1 DNA nuclear import may not be detectable in spreading assays due to the highly asynchronous infection process, as opposed to a more synchronous infection with viral vectors. Elements in the HIV-1 genome, not included in viral vectors, might also partially compensate for the lack of the cPPT. Recently, a more severe replication defect, consistent with the one found with HIV-1 based vectors, has been 
reported for different HIV-1 strains lacking the cPPT element in single cycle assays and spreading assays [167]. Even if the CPPT may not be absolutely essential for HIV1 replication, at least in tissue culture, this viral element remains a very interesting biological phenomenon and also has important practical applications in gene therapy.

\section{Cellular factors}

Mutations of all known viral karyophilic elements does not block HIV-1 replication [157], suggesting that viral components are unlikely to be the only factors regulating HIV-1 nuclear transport and that cellular factors need also to be investigated. One major problem in this case was the lack of a convenient in vitro assay to screen for potential cellular factors with HIV-1 nuclear import ability. The field of nuclear import has advanced at an impressive pace since the introduction in the early ' 90 s of the so-called "nuclear import assay" [168] (Figure 3). In this assay, the cell plasma membrane is permeabilized with digitonin, which solubilises cholesterol and hence leaves the nuclear envelope intact. Soluble intracellular components are washed out in buffer and nuclear import is artificially reconstituted by the addition of the fluorescent-tagged substrate of interest, cytoplasmic extracts or specific cellular factors, the Ran system and an energy regenerating system. The cells are incubated at 25 to $37^{\circ} \mathrm{C}$ for a short time, fixed and then analysed by confocal microscopy. Nuclear accumulation of the tagged substrate is detected when the right cellular components are added. Thus, this assay has allowed screening for many factors and has led to the identification of several importins or karyopherins [168171].

We have adapted this assay to investigate cellular components involved in HIV-1 nuclear trafficking (Figure 3). Purified HIV-1 RTCs are fluorescently labelled and added to the permeabilised cells, which can be HeLa or primary macrophages. This approach does not depend on mutations of viral proteins and putative nuclear import components can be tested individually, thus multiple and potentially redundant import pathways can be identified and dissected.

Using this approach we have recently found that importin 7 (imp7) stimulates nuclear import of HIV-1 RTCs and that siRNA-mediated depletion of imp7 inhibits HIV-1 infection, though only by a few fold [25]. Another study, however, using the siRNA approach, failed to see a phenotype in imp7 knock down cells and primary macrophages [172]. It should be noted that conflicting results were also reported for RNAi-mediated knock down of LEDGF/p75, which have cast doubts on the biological relevance of this proteins for HIV-1 replication [143,147,173]. A more radical knock-down of LEDGF/p75 has recently been reported to significantly affect viral replication, highlight- ing the fact that even small amounts of cellular factors are often sufficient to support normal HIV-1 replication (E. Poeschla, personal communication). The unambiguous role of LEDGF/p75 in HIV-1 replication is supported by recent LEDGF/p75 knock out studies (A. Engelman, personal communication). We have since observed that the efficiency HIV-1 but not SIVmac infection is reduced in stable imp7 shRNA knock down cell lines (Fassati et al. unpublished). However, the development of effective imp7 dominant negative mutants or cells with a condi-

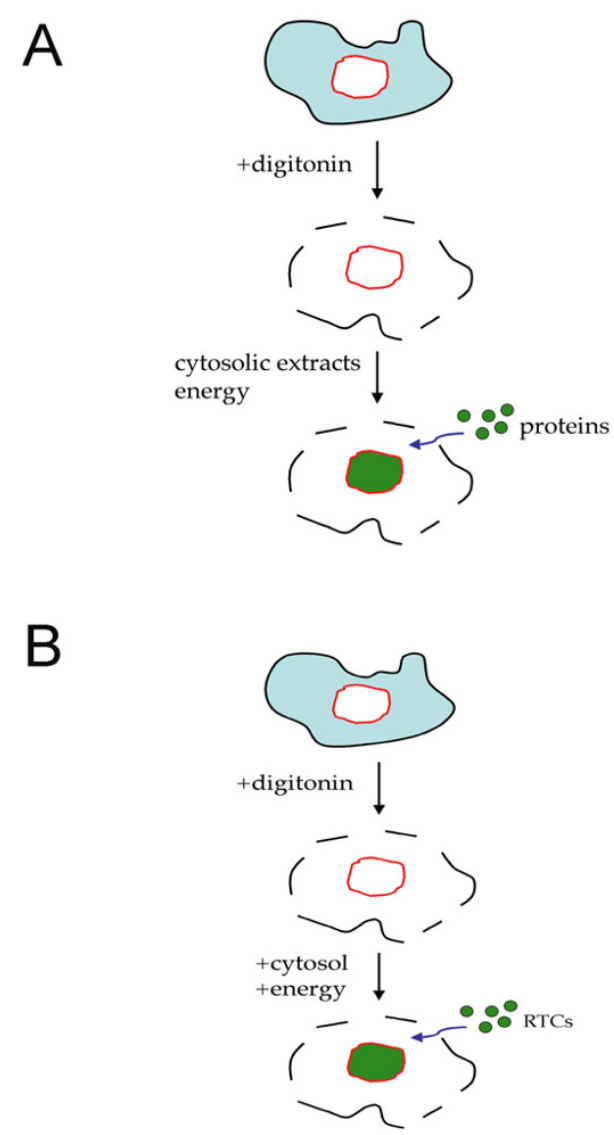

\section{Figure 3}

Schematic representation of the nuclear import assay. (A) The classic assay. Cells are permeabilized with digitonin, which leaves the nuclear envelope intact. The cytosol is washed out and nuclear import is reconstituted by addition of the protein of interest (labelled fluorescently), cytosolic extracts or nuclear import receptors, the Ran system (RanGDP, NTF2, RanGAP, RanBPI) and an energy regenerating system. Accumulation of the protein of interest is examined by confocal microscopy. (B) Adapted assay. The assay is carried out as described above but purified and labelled HIV-I RTCs are used instead of the protein of interest. 
tional imp7 knock out will probably be needed to investigate the full impact of this protein on the replication of HIV-1 and other retroviruses.

More recently we seek to identify additional cellular factors involved in nuclear import of HIV-1 RTCs. Using chromatographic procedures and the nuclear import assay we have isolated a near-homogeneous fraction from cytoplasmic extracts. This fraction contained tRNAs, most of them with defective 3' CCA ends. When synthesized in vitro, such tRNAs promoted HIV-1 RTC nuclear import. Moreover, tRNAs with RTC nuclear import activity were incorporated into and recovered from virus particles. We found that the anticodon loop mediated binding to the viral complex whilst the T-arm may interact with cellular components involved in nuclear import. These tRNAs species were transported into the nucleus on their own in a energy- and temperature-dependent way. We also observed that HIV-1 mutant containing MLV gag [74] did not incorporate tRNA species capable of promoting HIV1 RTC nuclear import and were impaired in infecting cell cycle-arrested cells [174]. Thus, by investigating HIV-1 nuclear import, we have found evidence for retrograde tRNA transport in mammalian cells, an unexpected process that has also been recently described in yeast $[175,176]$. Future work will hopefully elucidate which cellular factors participate in these events and whether the biological function of tRNA retrograde transport in mammalian cells is to modulate protein synthesis or is a tRNA quality control mechanism or both.

\section{Conclusion}

Elucidating the mechanisms of HIV-1 nuclear import is clearly a challenging area of research, both from a technical and a conceptual point of view. It is also a promising area of research, likely to reveal new and fundamental cellular pathways. To gain more insight and perhaps a little inspiration, it may be wise to look at similar processes occurring in cells, like mRNA export. Export of mRNA nucleoproteins (mRNPs) involves several factors. One of the best characterized is TAP or nuclear export factor 1 (NXF1) [177]. At least six other members of the NXF family have been described, some having little export activity, others having an mRNA-specific or cell type-specific export activity [177]. Interestingly, despite their sequence and structural similarity, different NXFs can use different export pathways and different modes to bind to NPCs [178]. NXFs need adaptors to engage with NPCs. One such adaptor is $\mathrm{p} 15$, which allows TAP bindng to nucleoporins. NXFs need adaptors also to bind to mRNAs. The socalled REF protein is an adaptor for TAP but additional adaptors include several exon-exon junction complex proteins. Moreover, the structure, shape and maturation stage of mRNAs influence their export rate and ATP-dependent motor proteins are required, probably at more than one stage [177]. The level of complexity and sometimes redundancy typical of mRNA export is well suited to illustrate the point: HIV-1 nuclear import is very likely to involve a similar or higher degree of complexity.

In conclusion, I would now like to propose a model on HIV-1 nuclear import. Many parts of this model are still hypothetical; nonetheless I shall be bold enough to put it to the attention and critical mind of the reader. After entry, HIV-1 starts reverse transcription and shortly thereafter sheds, partially or completely, its capsid. Such shedding is sufficient to expose the nucleoprotein complex or RTC, composed of the viral genome (presumably still in part RNA) and some viral and cellular proteins. The RTC then engages with the nuclear import machinery at several levels. There might be adaptors, both viral (for example Vpr) and cellular (for example tRNAs), that promote RTC docking and binding to the nuclear pores. Once at the nuclear pore, additional signals/factors may facilitate the charged and hydrophilic nucleic acids to cross the pore's central channel (for example imp7), and other elements may recruit putative motors at the pore to overcome the steep DNA concentration gradient in the nucleus (for example the CPPT element?). RTCs are likely to undergo substantial conformational changes at different stages (RTCs convert from RNA into double stranded DNA) and viral and cellular factors are also likely to associate and dissociate dynamically from the RTC. The multiplicity of signals ensures that the rate of nuclear transport is fast and individual signals may predominate in specific cell types. Like a good orchestra, the loss of one element will reduce the quality of the performance but, depending on the element lost, it may be noticeable only to the educated ear. It will be important to identify possible bottlenecks in this process to develop effective anti-viral strategies. MLV, on the other hand, may not be able to shed enough capsid to make its RTC fully visible to the nuclear import machinery and/or may lack sufficiently strong NLS [179]. MLV may be docked close to or at nuclear pores but then it may have to wait patiently until it is tethered to chromatin only after dissolution of the nuclear envelope.

There is of course a fundamental question worth considering: why mammalian cells have an evolutionary conserved mechanism to import DNA into their nuclei? Perhaps the study of nuclear import of viral genomes will shed some light on this problem too.

\section{Abbreviations}

HIV-1, human immunodeficiency virus type 1; SIV, simian immunodeficiency virus; MLV murine leukaemia virus; RTC, reverse transcription complex; IN, integrase; NPC, nuclear pore complex; cPPT, central polypurine tract; LEDGF, lens ephitelial-derived growth factor; MA, 
matrix protein; CA, capsid protein; mRNP, messenger RNA ribonucleoprotein.

\section{Competing interests}

The author(s) declare that they have no competing interests.

\section{Acknowledgements}

I thank Mary Collins, Steve Goff, Dirk Görlich, Luigi Naldini, Yasuhiro Takeuchi, Greg Towers, Robin Weiss and Lyuba Zaitseva for helpful discussions and Alan Engelman and Eric Poeschla for sharing their data prior to publication. AF is a Wellcome Trust University Fellow.

\section{References}

I. Sorin M, Kalpana GV: Dynamics of virus-host interplay in HIVI replication. Curr HIV Res 2006, 4: I 17-30.

2. Yamashita M, Emerman M: Retroviral infection of non-dividing cells: old and new perspectives. Virology 2006, 344:88-93.

3. Campbell EM, Hope TJ: Gene therapy progress and prospects: viral trafficking during infection. Gene Ther 2005, I 2: I353-9.

4. Lehmann-Che J, Saib A: Early stages of HIV replication: how to hijack cellular functions for a successful infection. AIDS Rev 2004, 6: 199-207.

5. Bukrinsky M: A hard way to the nucleus. Mol Med 2004, 10:I-5.

6. Lim RY, Aebi U, Stoffler D: From the trap to the basket: getting to the bottom of the nuclear pore complex. Chromosoma 2006, I I5:15-26.

7. Mattaj IW, Englmeier L: Nucleocytoplasmic transport: the soluble phase. Annu Rev Biochem 1998, 67:265-306.

8. Görlich D, Kutay U: Transport between the cell nucleus and the cytoplasm. Annu Rev Cell Dev Biol 1999, I5:607-660.

9. Nakielny S, Dreyfuss G: Transport of proteins and RNAs in and out of the nucleus. Cell 1999, 99:677-90.

10. Simos G, Grosshans H, Hurt E: Nuclear export of tRNA. In Nuclear transport Edited by: Weis K. Berlin: Springer-Verlag; 2002:133-150.

II. Izaurralde E: Nuclear export of messenger RNA. In Nuclear transport Edited by: Weis K. Berlin: Springer-Verlag; 2002:133-150.

12. Stoffler D, Goldie KN, Feja B, Aebi U: Calcium-mediated structural changes of native nuclear pore complexes monitored by time-lapse atomic force microscopy. J Mol Biol 1999, 287:74I-52.

13. Stoffler D, Feja B, Fahrenkrog B, Walz J, Typke D, Aebi U: Cryoelectron tomography provides novel insights into nuclear pore architecture: implications for nucleocytoplasmic transport. J Mol Biol 2003, 328: I 19-30.

14. Rout MP, Aitchison JD, Suprapto A, Hjertaas K, Zhao Y, Chait BT: The yeast nuclear pore complex: composition, architecture, and transport mechanism. J Cell Biol 2000, I 48:635-5I.

15. Walther TC, Pickersgill HS, Cordes VC, Goldberg MW, Allen TD, Mattaj IW, Fornerod M: The cytoplasmic filaments of the nuclear pore complex are dispensable for selective nuclear protein import. J Cell Biol 2002, I 58:63-77.

16. Cronshaw JM, Krutchinsky AN, Zhang W, Chait BT, Matunis MJ: Proteomic analysis of the mammalian nuclear pore complex. J Cell Biol 2002, I58:915-927.

17. Ben-Efraim I, Gerace L: Gradient of increasing affinity of importin beta for nucleoporins along the pathway of nuclear import. J Cell Biol 200I, I52:4I I-4I7.

18. Macara IG: Transport into and out of the nucleus. Microbiol Mol Biol Rev 200I, 65:570-94.

19. Ribbeck K, Gorlich D: The permeability barrier of nuclear pore complexes appears to operate via hydrophobic exclusion. $E M B O$ / 2002, $21: 2664-71$.

20. Siomi MC, Eder PS, Kataoka N, Wan L, Liu Q, Dreyfuss G: Transportin-mediated nuclear import of heterogeneous nuclear RNP proteins. J Cell Biol I997, I38: I I8I-I I 92.

21. Englmeier L, Olivo J-C, Mattaj IW: Receptor-mediated substrate translocation through the nuclear pore complex without nucleotide triphosphate hydrolysis. Curr Biol 1999, 14:30-4I.
22. Ribbeck K, Kutay U, Paraskeva E, Gorlich D: The translocation of transportin-cargo complexes through nuclear pores is independent of both Ran and energy. Curr Biol 1999, 9:47-50.

23. Lyman SK, Guan T, Bednenko J, Wodrich H, Gerace L: Influence of cargo size on Ran and energy requirements for nuclear protein import. J Cell Biol 2002, 159:55-67.

24. Schwoebel ED, Ho TH, Moore MS: The mechanism of inhibition of Ran-dependent nuclear transport by cellular ATP depletion. J Cell Biol 2002, I 57:963-74.

25. Fassati A, Gorlich D, Harrison I, Zaytseva L, Mingot JM: Nuclear import of HIV-I intracellular reverse transcription complexes is mediated by importin 7. EMBO | 2003, 22:3675-85.

26. Feldherr CM, Akin D: The permeability of the nuclear envelope in dividing and nondividing cell cultures. J Cell Biol 1990, I I I:I-8.

27. Feldherr CM, Akin D: Signal-mediated nuclear transport in proliferating and growth-arrested BALB/c 3T3 cells. J Cell Biol 1991, II 5:933-9.

28. Feldherr CM, Akin D: Regulation of nuclear transport in proliferating and quiescent cells. Exp Cell Res 1993, 205:179-86.

29. Feldherr C, Akin D: Stimulation of nuclear import by simian virus 40-transformed cell extracts is dependent on protein kinase activity. Mol Cell Biol 1995, I 2:7043-9.

30. Kehlenbach RH, Gerace L: Phosphorylation of the nuclear transport machinery down-regulates nuclear protein import in vitro. J Biol Chem 2000, 275: 17848-56.

31. Smith $A E$, Helenius $A$ : How viruses enter animal cells. Science 2004, 304:237-42.

32. Whittaker GR, Helenius A: Nuclear import and export of viruses and virus genomes. Virology 1998, 246:I-2.

33. Whittaker GR, Kann M, Helenius A: Viral entry into the nucleus. Annu Rev Cell Dev Biol 2000, 16:627-5I.

34. Greber UF, Fassati A: Nuclear import of viral DNA genomes. Traffic 2003, 4: I36-I43.

35. Hawkins RB: The influence of concentration of DNA on the radiosensitivity of mammalian cells. Int J Radiat Oncol Biol Phys 2005, 63:529-35.

36. Smith DE, Tans SJ, Smith SB, Grimes S, Anderson DL, Bustamante C: The bacteriophage straight phi29 portal motor can package DNA against a large internal force. Nature 200I, 4I3:748-52.

37. Anderson LW, Klevjer-Anderson P, Liggitt HD: Susceptibility of blood-derived monocytes and macrophages to caprine arthritis-encephalitis virus. Infect Immun 1983, 41:837-40.

38. Gendelman HE, Narayan O, Molineaux S, Clements JE, Ghotbi Z: Slow, persistent replication of lentiviruses: role of tissue macrophages and macrophage precursors in bone marrow. Proc Natl Acad Sci USA 1985, 82:7086-90.

39. Gendelman HE, Narayan O, Kennedy-Stoskopf S, Kennedy PG, Ghotbi Z, Clements JE, Stanley J, Pezeshkpour G: Tropism of sheep lentiviruses for monocytes: susceptibility to infection and virus gene expression increase during maturation of monocytes to macrophages. J Virol 1986, 58:67-74.

40. Ryan S, Tiley L, McConnell I, Blacklaws B: Infection of dendritic cells by the Maedi-Visna lentivirus. J Virol 2000, 74:10096- 10103.

41. Sellon DC, Perry ST, Coggins L, Fuller FJ: Wild-type equine infectious anemia virus replicates in vivo predominantly in tissue macrophages, not in peripheral blood monocytes. J Virol I992, 10:5906-13.

42. Ho DD, Rota TR, Hirsch MS: Infection of monocyte/macrophages by human T lymphotropic virus type III. J Clin Invest 1986, 77: $1712-5$.

43. Gartner S, Markovits P, Markovitz DM, Kaplan MH, Gallo RC, Popovic $M$ : The role of mononuclear phagocytes in HTLV-III/LAV infection. Science 1986, 233:215-9.

44. Salahuddin SZ, Rose RM, Groopman JE, Markham PD, Gallo RC: Human $\mathrm{T}$ lymphotropic virus type III infection of human alveolar macrophages. Blood 1986, 68:28I-284.

45. Ringler DJ, Wyand MS, Walsh DG, MacKey JJ, Sehgal PK, Daniel MD, Desrosiers RC, King NW: The productive infection of alveolar macrophages by simian immunodeficiency virus. J Med Primatol 1989, 18:217-226.

46. Ringler DJ, Wyand MS, Walsh DG, MacKey JJ, Chalifoux LV, Popovic M, Minassian AA, Sehgal PK, Daniel MD, Desrosiers RC, et al.: Cellular localization of simian immunodeficiency virus in lymphoid tissues. I. Immunohistochemistry and electron microscopy. Am J Pathol 1989, 134:373-83. 
47. Weinberg JB, Matthews TJ, Cullen BR, Malim MH: Productive human immunodeficiency virus type I (HIV-I) infection of nonproliferating human monocytes. J Exp Med 1991, I74:|477-|482.

48. Mehandru S, Poles MA, Tenner-Racz K, Horowitz A, Hurley A, Hogan C, Boden D, Racz P, Markowitz M: Primary HIV-I infection is associated with preferential depletion of CD4+ T lymphocytes from effector sites in the gastrointestinal tract. J Exp Med 2004, 200:76I-770.

49. Mattapallil J], Douek DC, Nishimura Y, Martin M, Roederer M: Massive infection and loss of memory CD4+ T cells in multiple tissues during acute SIV infection. Nature 2005, 434: 1093-1097.

50. Li Q, Duan L, Estes JD, Ma ZM, Rourke T, Wang Y, Reilly C, Carlis J, Miller C], Haase AT: Peak SIV replication in resting memory CD4+ $T$ cells depletes gut lamina propria CD4+ $T$ cells. Nature 2005, 434: I | 48-52.

5I. Gonzalez-Scarano F, Martin-Garcia J: The neuropathogenesis of AIDS. Nat Rev Immunol 2005, 5:69-8I.

52. Lewis $P$, Hensel $M$, Emerman $M$ : Human immunodeficiency virus infection of cells arrested in the cell cycle. EMBO J 1992, I I:3053-8.

53. Naldini L, Blomer U, Gage FH, Trono D, Verma IM: Efficient transfer, integration, and sustained long-term expression of the transgene in adult rat brains injected with a lentiviral vector. Proc Natl Acad Sci USA 1996, 93: I I382-8.

54. Case SS, Price MA, Jordan CT, Yu XJ, Wang L, Bauer G, Haas DL, Xu D, Stripecke R, Naldini L, Kohn DB, Crooks GM: Stable transduction of quiescent CD34(+)CD38(-) human hematopoietic cells by HIV-I-based lentiviral vectors. Proc Natl Acad Sci USA 1999, 96:2988-93.

55. Katz RA, Greger JG, Boimel P, Skalka AM: Human immunodeficiency virus type I DNA nuclear import and integration are mitosis independent in cycling cells. J Virol 2003, 77:13412-7.

56. Mannioui A, Schiffer C, Felix N, Nelson E, Brussel A, Sonigo P, Gluckman JC, Canque B: Cell cycle regulation of human immunodeficiency virus type $I$ integration in $T$ cells: antagonistic effects of nuclear envelope breakdown and chromatin condensation. Virology 2004, 329:77-88.

57. Groschel B, Bushman F: Cell cycle arrest in G2/M promotes early steps of infection by human immunodeficiency virus. Virol 2005, 79:5695-704.

58. Miller DG, Adam MA, Miller AD: Gene transfer by retrovirus vectors occurs only in cells that are actively replicating at the time of infection. Mol Cell Biol 1990, 10:4239-42.

59. Roe T, Reynolds TC, Yu G, Brown PO: Integration of murine leukemia virus DNA depends on mitosis. EMBO J 1993, 12:2099-108.

60. Lewis PF, Emerman M: Passage through mitosis is required for oncoretroviruses but not for the human immunodeficiency virus. J Virol 1994, 68:5 I0-6.

61. Jarrosson-Wuilleme L, Goujon C, Bernaud J, Rigal D, Darlix JL, Cimarelli A: Transduction of nondividing human macrophages with gammaretrovirus-derived vectors. / Virol 2006, 80: I I52-9.

62. Rubin H, Temin HM: A radiological study of cell-virus interaction in the Rous sarcoma. Virology 1959, 7:75-9|

63. Varmus HE, Padgett T, Heasley S, Simon G, Bishop JM: Cellular functions are required for the synthesis and integration of avian sarcoma virus-specific DNA. Cell 1977, I I:307-19.

64. Humphries EH, Glover C, Reichmann ME: Rous sarcoma virus infection of synchronized cells establishes provirus integration during S-phase DNA synthesis prior to cellular division. Proc Natl Acad Sci USA 198I, 78:260 I-5.

65. Hatziioannou T, Goff SP: Infection of nondividing cells by Rous sarcoma virus. I Virol 200I, 75:9526-3I.

66. Katz RA, Greger JG, Darby K, Boimel P, Rall GF, Skalka AM: Transduction of interphase cells by avian sarcoma virus. J Virol 2002 76:5422-34.

67. Greger JG, Katz RA, Taganov K, Rall GF, Skalka AM: Transduction of terminally differentiated neurons by avian sarcoma virus. Jirol 2004, 78:4902-4906

68. Saib A, Puvion-Dutilleul F, Schmid M, Peries J, de The H: Nuclear targeting of incoming human foamy virus $\mathbf{G a g}$ proteins involves a centriolar step. J Virol |997, 71: | |55-6I.

69. Linial ML: Foamy viruses are unconventional retroviruses. J Virol 1999, 73: 1747-55.
70. Mergia A, Chari S, Kolson DL, Goodenow MM, Ciccarone T: The efficiency of simian foamy virus vector type-I (SFV-I) in nondividing cells and in human PBLs. Virology 200I, 280:243-52.

7I. Trobridge G, Russell DW: Cell cycle requirements for transduction by foamy virus vectors compared to those of oncovirus and lentivirus vectors. J Virol 2004, 78:2327-35.

72. Josephson NC, Vassilopoulos G, Trobridge GD, Priestley GV, Wood BL, Papayannopoulou T, Russell DW: Transduction of human NOD/SCID-repopulating cells with both lymphoid and myeloid potential by foamy virus vectors. Proc Natl Acad Sci USA 2002, 99:8295-300.

73. Bieniasz PD, Weiss RA, McClure MO: Cell cycle dependence of foamy retrovirus infection. J Virol 1995, 69:7295-9.

74. Yamashita M, Emerman M: Capsid is a dominant determinant of retrovirus infectivity in nondividing cells. I Virol 2004 78:5670-8.

75. Dismuke DJ, Aiken C: Evidence for a functional link between uncoating of the human immunodeficiency virus type I core and nuclear import of the viral preintegration complex. J Virol 2006, 80:37|2-20.

76. Fassati A, Goff SP: Characterization of intracellular reverse transcription complexes of human immunodeficiency virus type I. J Virol 200I, 75:3626-35.

77. Forshey BM, von Schwedler U, Sundquist WI, Aiken C: Formation of a human immunodeficiency virus type I core of optimal stability is crucial for viral replication. J Virol 2002, 76:5667-77.

78. Farnet CM, Haseltine WA: Determination of viral proteins present in the human immunodeficiency virus type I preintegration complex. J Virol 1991, 65:1910-5.

79. Bukrinsky MI, Sharova N, McDonald TL, Pushkarskaya T, Tarpley WG, Stevenson M: Association of integrase, matrix, and reverse transcriptase antigens of human immunodeficiency virus type I with viral nucleic acids following acute infection. Proc Natl Acad Sci USA 1993, 90:6125-9.

80. Heinzinger NK, Bukinsky MI, Haggerty SA, Ragland AM, Kewalramani V, Lee MA, Gendelman HE, Ratner L, Stevenson M, Emerman M: The $\mathrm{Vpr}$ protein of human immunodeficiency virus type I influences nuclear localization of viral nucleic acids in nondividing host cells. Proc Natl Acad Sci USA 1994, 9 I :73 I I-5.

81. Miller MD, Farnet CM, Bushman FD: Human immunodeficiency virus type I preintegration complexes: studies of organization and composition. J Virol 1997, 71:5382-90.

82. Karageorgos L, Li P, Burrell C: Characterization of HIV replication complexes early after cell-to-cell infection. AIDS Res Hum Retroviruses 1993, 9:817-23.

83. Nermut MV, Fassati A: Structural analyses of purified human immunodeficiency virus type $I$ intracellular reverse transcription complexes. J Virol 2003, 77:8|96-206.

84. Jacqué JM, Triques K, Stevenson M: Modulation of HIV-I replication by RNA interference. Nature 2002, 4I 8:435-8.

85. Chiu YL, Soros VB, Kreisberg JF, Stopak K, Yonemoto W, Greene WC: Cellular APOBEC $3 \mathrm{G}$ restricts HIV-I infection in resting CD4+ T cells. Nature 2005, 435: I08-14.

86. Joshi PJ, North TW, Prasad VR: Aptamers directed to HIV-I reverse transcriptase display greater efficacy over small hairpin RNAs targeted to viral RNA in blocking HIV-I replication. Mol Ther 2005, I I:677-86.

87. Esterhout EM, ter Brake O, Berkhout B: The virion-associated incoming HIV-I RNA genome is not targeted by RNA interference. Retrovirology 2006, 4;3:57.

88. Stremlau M, Perron M, Lee M, Li Y, Song B, Javanbakht H, DiazGriffero F, Anderson DJ, Sundquist WI, Sodroski J: Specific recognition and accelerated uncoating of retroviral capsids by the TRIM5alpha restriction factor. Proc Natl Acad Sci USA 2006, I03:55I4-9.

89. Forshey BM, Shi J, Aiken C: Structural requirements for recognition of the human immunodeficiency virus type I core during host restriction in owl monkey cells. J Virol 2005, 79:869-75.

90. Perez-Caballero D, Hatziioannou T, Zhang F, Cowan S, Bieniasz PD: Restriction of human immunodeficiency virus type I by TRIM-CyPA occurs with rapid kinetics and independently of cytoplasmic bodies, ubiquitin, and proteasome activity. J Virol 2005, 79:15567-72

91. Risco C, Menendez-Arias L, Copeland TD, Pinto da Silva P, Oroszlan $\mathrm{S}$ : Intracellular transport of the murine leukemia virus during 
acute infection of NIH 3T3 cells: nuclear import of nucleocapsid protein and integrase. J Cell Sci 1995, 108:3039-50.

92. Fassati A, Goff SP: Characterization of intracellular reverse transcription complexes of Moloney murine leukemia virus. J Virol 1999, 73:8919-25.

93. Bowerman B, Brown PO, Bishop JM, Varmus HE: A nucleoprotein complex mediates the integration of retroviral DNA. Genes Dev 1989, 3:469-78.

94. Yuan B, Fassati A, Yueh A, Goff SP: Characterization of Moloney murine leukemia virus pl 2 mutants blocked during early events of infection. J Virol 2002, 76: $1080 \mathrm{I}-10$.

95. Yueh A, Leung J, Bhattacharyya S, Perrone LA, de los Santos K, Pu SY, Goff SP: Interaction of moloney murine leukemia virus capsid with Ubc9 and PIASy mediates SUMO-I addition required early in infection. / Virol 2006, 80:342-52.

96. Mahajan R, Delphin C, Guan T, Gerace L, Melchior F: A small ubiquitin-related polypeptide involved in targeting RanGAPI to nuclear pore complex protein RanBP2. Cell 1997, 88:97-107.

97. Joseph J, Liu ST, Jablonski SA, Yen TJ, Dasso M: The RanGAPIRanBP2 complex is essential for microtubule-kinetochore interactions in vivo. Curr Biol 2004, 14:6 II-7.

98. Bukrinsky MI, Haggerty S, Dempsey MP, Sharova N, Adzhubel A, Spitz L, Lewis P, Goldfarb D, Emerman M, Stevenson M: A nuclear localization signal within HIV-I matrix protein that governs infection of non-dividing cells. Nature 1993, 365:666-9.

99. von Schwedler U, Kornbluth RS, Trono D: The nuclear localization signal of the matrix protein of human immunodeficiency virus type $I$ allows the establishment of infection in macrophages and quiescent T lymphocytes. Proc Natl Acad Sci USA 1994, 91:6992-6.

100. Gallay P, Swingler S, Aiken C, Trono D: HIV-I infection of nondividing cells: C-terminal tyrosine phosphorylation of the viral matrix protein is a key regulator. Cell 1995, 80:379-88.

101. Gallay P, Swingler S, Song J, Bushman F, Trono D: HIV nuclear import is governed by the phosphotyrosine-mediated binding of matrix to the core domain of integrase. Cell 1995, 83:569-76.

102. Bukrinskaya AG, Ghorpade A, Heinzinger NK, Smithgall TE, Lewis RE, Stevenson M: Phosphorylation-dependent human immunodeficiency virus type $I$ infection and nuclear targeting of viral DNA. Proc Natl Acad Sci USA 1996, 93:367-7I.

103. Freed EO, Englund G, Maldarelli F, Martin MA: Phosphorylation of residue I 3 I of HIV-I matrix is not required for macrophage infection. Cell 1997, 88: $17 \mid-3$.

104. Freed EO, Englund G, Martin MA: Role of the basic domain of human immunodeficiency virus type I matrix in macrophage infection. J Virol 1995, 69:3949-54.

105. Fouchier RA, Meyer BE, Simon JH, Fischer U, Malim MH: HIV-I infection of non-dividing cells: evidence that the amino-terminal basic region of the viral matrix protein is important for Gag processing but not for post-entry nuclear import. EMBO J 1997, 16:4531-9.

106. Depienne C, Roques P, Creminon C, Fritsch L, Casseron R, Dormont D, Dargemont C, Benichou S: Cellular distribution and karyophilic properties of matrix, integrase, and $\mathrm{Vpr}$ proteins from the human and simian immunodeficiency viruses. Exp Cell Res 2000, 260:387-95.

107. Mannioui A, Nelson E, Schiffer C, Felix N, Le Rouzic E, Benichou S, Gluckman JC, Canque B: Human immunodeficiency virus type I KK26-27 matrix mutants display impaired infectivity, circularization and integration but not nuclear import. Virology 2005, 339:2I-30.

108. Reil H, Bukovsky AA, Gelderblom HR, Gottlinger HG: Efficient HIV-I replication can occur in the absence of the viral matrix protein. EMBO J 1998, 17:2699-708.

109. Dupont S, Sharova N, DeHoratius C, Virbasius CM, Zhu X, Bukrinskaya AG, Stevenson M, Green MR: A novel nuclear export activity in HIV-I matrix protein required for viral replication. Nature 1999, 402:68I-5.

1 10. Haffar OK, Popov S, Dubrovsky L, Agostini I, Tang H, Pushkarsky T, Nadler SG, Bukrinsky M: Two nuclear localization signals in the HIV-I matrix protein regulate nuclear import of the HIV-I pre-integration complex. J Mol Biol 2000, 299:359-68.

III. Gallay P, Hope T, Chin D, Trono D: HIV-I infection of nondividing cells through the recognition of integrase by the impor- tin/karyopherin pathway. Proc Natl Acad Sci USA 1997, 94:9825-30

112. Le Rouzic E, Benichou S: The Vpr protein from HIV-I: distinct roles along the viral life cycle. Retrovirology 2005, 2:I I.

113. Lu YL, Spearman P, Ratner L: Human immunodeficiency virus type I viral protein $\mathbf{R}$ localization in infected cells and virions. J Virol 1993, 67:6542-50.

II4. Di Marzio P, Choe S, Ebright M, Knoblauch R, Landau NR: Mutational analysis of cell cycle arrest, nuclear localization and virion packaging of human immunodeficiency virus type I Vpr. J Virol 1995, 69:7909-16.

115. Mahalingam S, Collman RG, Patel M, Monken CE, Srinivasan A: Functional analysis of HIV-I Vpr: identification of determinants essential for subcellular localization. Virology 1995, 2 | 2:33 |-9.

I 16. Fouchier RA, Meyer BE, Simon JH, Fischer U, Albright AV, GonzalezScarano F, Malim MH: Interaction of the human immunodeficiency virus type I $\mathrm{Vpr}$ protein with the nuclear pore complex. J Virol 1998, 72:6004-I3.

117. Jenkins Y, McEntee M, Weis K, Greene WC: Characterization of HIV-I vpr nuclear import: analysis of signals and pathways. Cell Biol 1998, I43:875-85.

I 18. Vodicka MA, Koepp DM, Silver PA, Emerman M: HIV-I Vpr interacts with the nuclear transport pathway to promote macrophage infection. Genes Dev 1998, 12:175-85.

119. Le Rouzic E, Mousnier A, Rustum C, Stutz F, Hallberg E, Dargemont C, Benichou S: Docking of HIV-I Vpr to the nuclear envelope is mediated by the interaction with the nucleoporin hCGI. J Biol Chem 2002, 277:4509I-8.

120. Gallay P, Stitt V, Mundy C, Oettinger M, Trono D: Role of the karyopherin pathway in human immunodeficiency virus type $I$ nuclear import. J Virol 1996, 70:1027-32.

121. Paxton W, Connor RI, Landau NR: Incorporation of Vpr into human immunodeficiency virus type I virions: requirement for the p6 region of gag and mutational analysis. J Virol 1993 , 67:7229-37

122. Jenkins Y, Sanchez PV, Meyer BE, Malim MH: Nuclear export of human immunodeficiency virus type I $\mathrm{Vpr}$ is not required for virion packaging. J Virol 200I, 75:8348-52.

123. Sherman MP, de Noronha CM, Eckstein LA, Hataye J, Mundt P, Williams SA, Neidleman JA, Goldsmith MA, Greene WC: Nuclear export of $\mathrm{Vpr}$ is required for efficient replication of human immunodeficiency virus type I in tissue macrophages. J Virol 2003, 77:7582-9.

124. McDonald D, Vodicka MA, Lucero G, Svitkina TM, Borisy GG, Emerman M, Hope TJ: Visualization of the intracellular behavior of HIV in living cells. J Cell Biol 2002, I 59:44I-52.

125. Popov S, Rexach M, Ratner L, Blobel G, Bukrinsky M: Viral protein $R$ regulates docking of the HIV-I preintegration complex to the nuclear pore complex. J Biol Chem 1998, 273:13347-52.

126. de Noronha CM, Sherman MP, Lin HW, Cavrois MV, Moir RD, Goldman RD, Greene WC: Dynamic disruptions in nuclear envelope architecture and integrity induced by HIV-I Vpr. Science 200I, 294: $1105-8$

127. Connor RI, Chen BK, Choe S, Landau NR: Vpr is required for efficient replication of human immunodeficiency virus type- $I$ in mononuclear phagocytes. Virology 1995, 206:935-44.

128. Zufferey R, Nagy D, Mandel RJ, Naldini L, Trono D: Multiply attenuated lentiviral vector achieves efficient gene delivery in vivo. Nat Biotechnol 1997, I 5:87I-5.

129. Fletcher TM 3rd, Brichacek B, Sharova N, Newman MA, Stivahtis G, Sharp PM, Emerman M, Hahn BH, Stevenson M: Nuclear import and cell cycle arrest functions of the HIV-I Vpr protein are encoded by two separate genes in HIV-2/SIV(SM). EMBO J 1996, 15:6155-65.

130. Gibbs JS, Lackner AA, Lang SM, Simon MA, Sehgal PK, Daniel MD, Desrosiers RC: Progression to AIDS in the absence of a gene for vpr or vpx. J Virol 1995, 69:2378-83.

13I. Hirsch VM, Sharkey ME, Brown CR, Brichacek B, Goldstein S, Wakefield J, Byrum R, Elkins WR, Hahn BH, Lifson JD, Stevenson M: Vpx is required for dissemination and pathogenesis of $\operatorname{SIV}(\mathrm{SM})$ PBj: evidence of macrophage-dependent viral amplification. Nat Med 1998, 4: I40I-8.

132. Petit C, Schwartz O, Mammano F: The karyophilic properties of human immunodeficiency virus type $I$ integrase are not required for nuclear import of proviral DNA. / Virol 2000, 74:7119-26. 
133. Depienne C, Mousnier A, Leh H, Le Rouzic E, Dormont D, Benichou $S$, Dargemont C: Characterization of the nuclear import pathway for HIV-I integrase. J Biol Chem 200I, 276: I8I02-7.

134. Ao Z, Fowke KR, Cohen EA, Yao X: Contribution of the C-terminal tri-lysine regions of human immunodeficiency virus type I integrase for efficient reverse transcription and viral DNA nuclear import. Retrovirology 2005, 2:62.

135. Ikeda T, Nishitsuji H, Zhou X, Nara N, Ohashi T, Kannagi M, Masuda $T$ : Evaluation of the functional involvement of human immunodeficiency virus type I integrase in nuclear import of viral cDNA during acute infection. J Virol 2004, 78: I I 563-73.

136. Tsurutani N, Kubo M, Maeda Y, Ohashi T, Yamamoto N, Kannagi M, Masuda $\mathrm{T}$ : Identification of critical amino acid residues in human immunodeficiency virus type I IN required for efficient proviral DNA formation at steps prior to integration in dividing and nondividing cells. J Virol 2000, 74:4795-806.

137. Maertens G, Cherepanov P, Pluymers W, Busschots K, De Clercq E, Debyser Z, Engelborghs Y: LEDGF/p75 is essential for nuclear and chromosomal targeting of HIV-I integrase in human cells. I Biol Chem 2003, 278:33528-39.

138. Hearps AC, Jans DA: HIV-I integrase is capable of targeting DNA to the nucleus via an importin alpha/beta dependent mechanism. Biochem / 2006, 398:475-484.

139. Arnold M, Nath A, Hauber J, Kehlenbach RH: Multiple importins function as nuclear transport receptors for the Rev protein of the human immunodeficiency virus type I. J Biol Chem 2006, 28I:20883-90.

140. Wodrich H, Cassany A, D'Angelo MA, Guan T, Nemerow G, Gerace $\mathrm{L}$ : Adenovirus core protein $\mathrm{pVII}$ is translocated into the nucleus by multiple import receptor pathways. J Virol 2006, 80:9608-18.

14I. Jakel S, Gorlich D: Importin beta, transportin, RanBP5 and RanBP7 mediate nuclear import of ribosomal proteins in mammalian cells. EMBO J I998, I 7:449|-502.

142. Cherepanov P, Maertens G, Proost P, Devreese B, Van Beeumen J, Engelborghs $Y$, De Clercq E, Debyser Z: HIV-I integrase forms stable tetramers and associates with LEDGF/p75 protein in human cells. J Biol Chem 2003, 278:372-8I

143. Llano M, Vanegas M, Fregoso O, Saenz D, Chung S, Peretz M, Poeschla EM: LEDGF/p75 determines cellular trafficking of diverse lentiviral but not murine oncoretroviral integrase proteins and is a component of functional lentiviral preintegration complexes. J Virol 2004, 78:9524-37.

144. Llano M, Delgado S, Vanegas M, Poeschla EM: Lens epitheliumderived growth factor/p75 prevents proteasomal degradation of HIV-I integrase. J Biol Chem 2004, 279:55570-7.

145. Maertens G, Cherepanov P, Debyser Z, Engelborghs Y, Engelman A: Identification and characterization of a functional nuclear localization signal in the HIV-I integrase interactor LEDGF/ p75. J Biol Chem 2004, 279:3342I-9.

146. Vanegas M, Llano M, Delgado S, Thompson D, Peretz M, Poeschla E: Identification of the LEDGF/p75 HIV-I integrase-interaction domain and NLS reveals NLS-independent chromatin tethering. J Cell Sci 2005, I I 8: I733-43.

147. Vandekerckhove L, Christ F, Van Maele B, De Rijck J, Gijsbers R, Van den Haute $C$, Wityrouw $M$, Debyser $Z$. Transient and stable knockdown of the integrase cofactor LEDGF/p75 reveals its role in the replication cycle of human immunodeficiency virus. I Virol 2006, 80:।886-96.

148. Cherepanov P, Sun ZY, Rahman S, Maertens G, Wagner G, Engelman A: Solution structure of the HIV-I integrase-binding domain in LEDGF/p75. Nat Struct Mol Biol 2005, I 2:526-32.

149. Devroe E, Engelman A, Silver PA: Intracellular transport of human immunodeficiency virus type I integrase. I Cell Sci 2003, I I 6:440 I-8.

150. Kukolj G, Jones KS, Skalka AM: Subcellular localization of avian sarcoma virus and human immunodeficiency virus type I integrases. J Virol 1997, 7 I:843-7.

I5I. Gao K, Butler SL, Bushman F: Human immunodeficiency virus type I integrase: arrangement of protein domains in active cDNA complexes. EMBO J 200I, 20:3565-76.

152. Bouyac-Bertoia M, Dvorin JD, Fouchier RA, Jenkins Y, Meyer BE, Wu $\mathrm{LI}$, Emerman M, Malim MH: HIV-I infection requires a functional integrase NLS. Mol Cell 2001, 7:1025-35

153. Dvorin JD, Bell P, Maul GG, Yamashita M, Emerman M, Malim MH Reassessment of the roles of integrase and the central DNA flap in human immunodeficiency virus type I nuclear import. J Virol 2002, 76: I 2087-96.

154. Limon A, Nakajima N, Lu R, Ghory HZ, Engelman A: Wild-type levels of nuclear localization and human immunodeficiency virus type I replication in the absence of the central DNA flap. J Virol 2002, 76: I2078-86.

155. Limon A, Devroe E, Lu R, Ghory HZ, Silver PA, Engelman A: Nuclear localization of human immunodeficiency virus type I preintegration complexes (PICs): VI65A and RI66A are pleiotropic integrase mutants primarily defective for integration, not PIC nuclear import. J Virol 2002, 76: I0598-607

156. Lu R, Limon A, Devroe E, Silver PA, Cherepanov P, Engelman A Class II integrase mutants with changes in putative nuclear localization signals are primarily blocked at a postnuclear entry step of human immunodeficiency virus type I replication. J Virol 2004, 78: 12735-46.

I57. Yamashita M, Emerman M: The cell cycle independence of HIV infections is not determined by known karyophilic viral elements. PLoS Pathog 2005, I(3):e I8.

158. Charneau P, Alizon M, Clavel F: A second origin of DNA plusstrand synthesis is required for optimal human immunodeficiency virus replication. J Virol 1992, 66:2814-20.

159. Charneau P, Clavel F: A single-stranded gap in human immunodeficiency virus unintegrated linear DNA defined by a central copy of the polypurine tract. J Virol I99|, 65:24I5-2I.

160. Zennou V, Petit C, Guetard D, Nerhbass U, Montagnier L, Charneau P: HIV-I genome nuclear import is mediated by a central DNA flap. Cell 2000, I $01: 173-85$

16I. Follenzi A, Ailles LE, Bakovic S, Geuna M, Naldini L: Gene transfer by lentiviral vectors is limited by nuclear translocation and rescued by HIV-I pol sequences. Nat Genet 2000, 25:217-22.

162. Zennou V, Serguera C, Sarkis C, Colin P, Perret E, Mallet J, Charneau P: The HIV-I DNA flap stimulates HIV vector-mediated cell transduction in the brain. Nat Biotechnol 200I, 19:446-50.

163. Manganini M, Serafini M, Bambacioni F, Casati C, Erba E, Follenzi A, Naldini L, Bernasconi S, Gaipa G, Rambaldi A, Biondi A, Golay J, Introna $M$ : A human immunodeficiency virus type I pol genederived sequence (cPPT/CTS) increases the efficiency of transduction of human nondividing monocytes and $T$ lymphocytes by lentiviral vectors. Hum Gene Ther 2002 I 3: | 793-807.

164. Van Maele B, De Rijck J, De Clercq E, Debyser Z: Impact of the central polypurine tract on the kinetics of human immunodeficiency virus type I vector transduction. J Virol 2003, 77:4685-94.

165. Ao Z, Yao X, Cohen EA: Assessment of the role of the central DNA flap in human immunodeficiency virus type I replication by using a single-cycle replication system. J Virol 2004, 78:3170-7.

166. Heyman T, Wilhelm M, Wilhelm FX: The central PPT of the yeast retrotransposon $\mathrm{TyI}$ is not essential for transposition. J Mol Biol 2003, 33 I:3 I5-20.

167. Arhel N, Munier S, Souque P, Mollier K, Charneau P: Nuclear import defect of human immunodeficiency virus type I DNA flap mutants is not dependent on the viral strain or target cell type. J Virol 2006, 80:10262-9.

168. Adam SA, Marr RS, Gerace L: Nuclear protein import in permeabilized mammalian cells requires soluble cytoplasmic factors. I Cell Biol 1990, I I I:807-16.

169. Adam SA, Gerace L: Cytosolic proteins that specifically bind nuclear location signals are receptors for nuclear import. Cell 1991, 66:837-47.

170. Moore MS, Blobel G: The two steps of nuclear import, targeting to the nuclear envelope and translocation through the nuclear pore, require different cytosolic factors. Cell 1992 69:939-50.

17I. Gorlich D, Prehn S, Laskey RA, Hartmann E: Isolation of a protein that is essential for the first step of nuclear protein import. Cell 1994, 79:767-78.

172. Zielske SP, Stevenson M: Importin 7 may be dispensable for human immunodeficiency virus type I and simian immunodeficiency virus infection of primary macrophages. J Virol 2005, 79: II $541-6$.

173. Vandegraaff N, Devroe E, Turlure F, Silver PA, Engelman A: Biochemical and genetic analyses of integrase-interacting proteins lens epithelium-derived growth factor (LEDGF)/p75 
and hepatoma-derived growth factor related protein 2 (HRP2) in preintegration complex function and HIV-I replication. Virology 2006, 346:4I5-26.

174. Zaitseva L, Mayers R, Fassati A: tRNAs promote nuclear import of HIV-I intracellular reverse transcription complexes. PloS Biol 4(I0):e332.

175. Takano A, Endo T, Yoshihisa T: tRNA actively shuttles between the nucleus and cytosol in yeast. Science 2005, 309: I40-I 42.

176. Shaheen HH, Hopper AK: Retrograde movement of tRNAs from the cytoplasm to the nucleus in Saccaromyces cervisiae. Proc Natl Acad Sci USA 2005, 102: I I 290-I I 295.

177. Erkmann JA, Kutay U: Nuclear export of mRNA: from the site of transcription to the cytoplasm. Exp Cell Res 2004, 296:12-20.

178. Yang J, Bogerd HP, Wang PJ, Page DC, Cullen BR: Two closely related human nuclear export factors utilize entirely distinct export pathways. Mol Cell 200I, 8:397-406.

179. $\mathrm{YuJH}$, Schaffer DV: High-throughput, library-based selection of a murine leukemia virus variant to infect nondividing cells. J Virol 2006, 80:898I-8.

Publish with Bio Med Central and every scientist can read your work free of charge

"BioMed Central will be the most significant development for disseminating the results of biomedical research in our lifetime. "

Sir Paul Nurse, Cancer Research UK

Your research papers will be:

- available free of charge to the entire biomedical community

- peer reviewed and published immediately upon acceptance

- cited in PubMed and archived on PubMed Central

- yours - you keep the copyright

Submit your manuscript here:

http://www.biomedcentral.com/info/publishing_adv.asp
BiolMedcentral 